Andrews University

Digital Commons @ Andrews University

Faculty Publications

$4-10-2020$

\title{
Unity in Diversity: How Music Helped Shape the Spiritual Identities of Black and White Seventh-Day Adventists, 1840-1944
}

David A. Williams

Andrews University, wdavid@andrews.edu

Follow this and additional works at: https://digitalcommons.andrews.edu/pubs

Part of the Liturgy and Worship Commons

\section{Recommended Citation}

Williams, David A., "Unity in Diversity: How Music Helped Shape the Spiritual Identities of Black and White Seventh-Day Adventists, 1840-1944" (2020). Faculty Publications. 1201.

https://digitalcommons.andrews.edu/pubs/1201

This Article is brought to you for free and open access by Digital Commons @ Andrews University. It has been accepted for inclusion in Faculty Publications by an authorized administrator of Digital Commons @ Andrews University. For more information, please contact repository@andrews.edu. 


\section{Unity in Diversity: How Music Helped Shape the Spiritual Identities of Black and White Seventh-Day Adventists, 1840-1944}

\section{David A. Williams}

To cite this article: David A. Williams (2020) Unity in Diversity: How Music Helped Shape the Spiritual Identities of Black and White Seventh-Day Adventists, 1840-1944, Liturgy, 35:2, 33-41, DOI: $10.1080 / 0458063 X .2020 .1739480$

To link to this article: https://doi.org/10.1080/0458063X.2020.1739480

曲 Published online: 10 Apr 2020.

Submit your article to this journal 전

LII Article views: 9

Q View related articles $\sqsubset$

View Crossmark data $\nearrow$ 


\title{
Unity in Diversity: How Music Helped Shape the Spiritual Identities of Black and White Seventh-Day Adventists, 1840-1944
}

\author{
David A. Williams \\ Andrews University, Berrien Spring, Michigan, USA
}

Keywords: music, worship, spiritual identity, spirituality, Black, White, racism, ethnicity, unity, diversity

Many Christian denominations are witnessing an ever-increasing diversity of ethnicities in their local congregations. Though a locally diverse congregation may ascribe to denominational beliefs, the different ethnicities may manifest their worship differently. When we express our worship so differently, it becomes apparent that not all share the same identity. A diversity of spiritual identities is expressed and cultivated in worship. Can there be a plurality of cultural identities, while also maintaining a core spiritual identity within a denomination?

This paper approaches the topic of spiritual identities through the historical development of the Seventh-day Adventist Church. It springs from my doctoral dissertation in which I compared the worship and music practices of Black and White Adventists from their beginning in the 1840s until the 1940s, when the denomination established Regional Conferences for dedicated Black ministry. ${ }^{1}$ Black and White Adventists have maintained a shared spirituality, unified through a common identity regarding the love of God in Christ, the second coming, and the Sabbath. However, based on differences in societal standing and human need, these ethnicities have cultivated different spiritual identities as well. Music played an important role in shaping a shared Adventist spiritual identity, but also in expressing unique identities based on the Black and White American experience. Music played an important role in cultivating unity in diversity.

\section{Understanding Spiritual Identity}

Exploring the spiritual identity of Black and White Americans demands definitional consideration. From a biblical perspective, there is only one human race created by God. ${ }^{2}$ Through their storied past, Americans have wrestled with race. Historically, biological distinctions, such as appearance, skin color, hair color and texture, and facial features, defined racial categories. ${ }^{3}$ Today, this view is widely discredited. New research points toward understanding race as a "social construction" of "how people see each other [and] how they define their own identity." Race plays a prominent role in identity formation, placing individuals into demographic groups, such as ascribing to a certain faith tradition. Black and White are cultural constructs, possessing shared, but also distinctive, cultural identifiers such as food, dress, language, and music. Music forms a community, expressing a culture's esthetics and values. Dirk Ellis affirms, "there exists a close connection between what a church and its people believe, and in time become, and what 
they sing." ${ }^{\prime 5}$ A shared musical corpus demonstrates a shared identity, but the manner in which that same corpus is performed also reveals distinct identities.

More broadly, religion functions as a means of identification. "It tells us who we are." Music in religious ritual becomes a "way of identifying one's self and stating to which group one belongs." ${ }^{7}$ Music expresses spirituality, ${ }^{8}$ and each idiom is a "carrier of social customs, of ritual

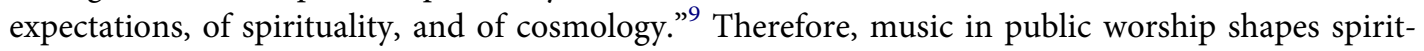
ual identity, the sum of beliefs and values that make up the religious life.

\title{
Forging a New Adventist Identity through Music
}

Adventism began as the Millerite movement-an interdenominational faith of the early 1840s. The identity of the movement centered on heralding the soon-to-appear, literal second coming of Jesus Christ. The movement received its name from its first preacher, William Miller, who, in 1833, began publicly preaching the "cleansing of the sanctuary"-the earth-would occur at Christ's second coming. During late Fall 1839, the movement gained rapid momentum when Joshua V. Himes (1805-1895) converted to the message. ${ }^{10}$ A shrewd publicist, Himes promoted the movement through event planning and the publication of a journal, The Signs of the Times, later called The Advent Herald. The movement's adherents called themselves Adventists, for they eagerly awaited Christ's second advent. Miller claimed 200 ministers embraced the message; 1,000 congregations were raised up; 6,000 conversions, 700 persons of no faith; and over 50,000 believers.

Music was a hallmark of the movement, a unifier of its distinct message:

You will see your Lord a-coming,
You will see your Lord a-coming,
You will see your Lord a-coming,
While the old church yards,
Hear the band of music,
Hear the band of music,
Hear the band of music,
Which is sounding thro' the air.

Commonly known as "Old Church Yard," this song was a hit. It captured the essence of the movement. James Springer White (1821-1881), one of the leading pioneers of the Seventh-day Adventist Church, enjoyed employing this song as a rousing call to worship. The "sweet melody" held "nearly a thousand persons in breathless silence," none moving until the song was finished. ${ }^{12}$ One incident in which he and his two sisters performed the song as a meditation before the celebration of the Lord's Supper, provides a rich description for consideration.

\begin{abstract}
Our voices were in those days clear and powerful, and our spirits triumphant in the Lord. And as we would strike the chorus of each verse- "With a band of music,"-a good Bro. Clark, who ever seemed to have resting upon him a solemn sense of the great day of God near at hand, would rise, strike his hands together over his head, shout "Glory!" and immediately sit down. A more solemn appearing man I never saw. Each repetition of this chorus would bring Bro. Clark to his feet, and call from him the same shout of glory. The Spirit of God came upon the brethren, who by this time were seated ready to receive the emblems of our dying Lord. The influence of the melody, accompanied by Bro. Clark's solemn appearance and sweet shouts, seemed electrifying. Many were in tears, while responses of "Amen," and "Praise the Lord," were heard from almost every one who loved the Advent hope. The emblems were passed, and that yearly meeting closed. ${ }^{13}$
\end{abstract}

By singing this song, worshipers embedded a second-coming spirituality deep within their identity. While singing the song, by faith they transported their imagination to the eschaton, joining that heavenly band. Clark's standing symbolized the rising of saints to meet Christ in the clouds of glory.

The Millerites, however, met bitter disappointment on October 22, 1844-the date they anticipated Christ would return to cleanse the world with fire. As they turned to re-orienting their 
lives, many sought to understand what had happened. Adventism divided into factions, most maintaining some degree of faith in the second coming.

- Some abandoned Adventism, rejecting Christ's coming altogether.

- Some believed the date was wrong but continued to believe Christ would return soon. Most Millerites, including Miller and Himes, adopted this view. Until his death, William Miller continued in the hope that his friend, Jesus, would return soon one day.

- Some believed he came spiritually, that is, to their souls.

- Some came to understand that something else had happened on that date and that Christ's second coming was still in the future. Through Bible study, this group reinterpreted the date as a shift in the High Priestly role of Christ, as he transitioned into the anti-typical Day of Atonement. ${ }^{14}$

The latter of these groups, a "little flock," soon adopted the seventh-day Sabbath. Scholars termed them Sabbatarian Adventist, a designation that lasted until 1860 when the group took the name Seventh-day Adventist. They organized as a church in $1861 .^{15}$

During the Sabbatarian Adventist period (1844-1860), the little Adventist flock witnessed a great frequency of hymnbook publications, publishing five hymnals and four supplements edited by James White. The first book of any size published by Adventists was the 1849 Hymns for God's Peculiar People. ${ }^{16}$ Publishing a songbook of nearly fifty pages containing key theological concepts, leveraged music as a catalyst to promote unity among the flock, and their unique perspective among the Adventist factions.

Christ's return and the hope of heaven continued to be paramount in the Sabbatarian Adventist spirituality, often expressing this hope through poetry submitted to the movement's periodical, the Review and Herald, short for the Advent Review and Sabbath Herald later called the Adventist Review, and today, the Review. (Adventists tend to refer simply to $R H$ for this array of publication names). ${ }^{17}$ Christ's coming will be musical, for heaven is a musical place. ${ }^{18}$

There will be in heaven worship, doubtless, in its gentlest song, and its loudest and universal acclaim-all the harmonies of its sound; the involved and exciting mysteries of music; the powers of its eloquence and its expression exhausted on that work of praise, when the redeemed shall cry: "Worthy is the Lamb." ... How great a matter it will be, to be found at length in heaven. How amazing! "Then to grace how great a debtor!"19

The last phrase alludes to the hymn, "Come Thou Fount." The Review and Herald thus allowed Adventists to share new hymns that were supporting their spirituality. Sabbatarian Adventists sought to imitate heavenly glory by means of their music in worship on earth. Christ's coming meant not only an eschatological hope, but a culmination of earthly singing and participation in the music of heaven.

Singing the faith roots one in that faith. Adventism has followed a very similar course as other Christian traditions before it. Lutheranism, for example, has its chorales; Methodism, its Wesleyan hymns; and Adventism, its second coming hymns. Singing, doctrine, and spiritual identity are intimately tied. Interestingly, much emphasis has been placed on the fact that Adventists have gathered for worship on Saturday as if that was the locus of their spiritual ethos. While significant, it should not overshadow the fervor of their faith in the second coming, exemplified in songs of their Savior Who is coming back. Then will come the eschatological Sabbath, when all God's children will rest in His grace for all eternity. Singing second-coming hymns on the weekly Sabbath typified their eschatology. Music played an indispensable role in establishing a sense of mission, movement, and identity for the little flock that ultimately became the Seventh-day Adventist Church. Music helped foster a shared identity, linking diverse people around the globe. 


\section{Spiritual Identities in Black and White}

Early Adventist pioneers were ardent abolitionists, leading many Northern Blacks to the Adventist message of judgment and the soon return of Christ. From the North, they supported the liberation of Black slaves, while pointing to ultimate freedom at Christ's coming. Early in Adventism, Black ministers made an important impact upon both Black and White Adventist congregations, preaching in both contexts. ${ }^{20}$ Blacks and Whites continued to worship together, especially at general conferences. The evidence seems to suggest that some congregations worshiped jointly, while others gathered separately. Regardless, Black and White Adventists followed an inherited free-church "hymn-sandwich" liturgical pattern: opening hymn, prayer, hymn, Scripture, sermon, and a closing hymn. While the liturgy became more complex over the twentieth century, Blacks and Whites followed markedly similar liturgies. In 1932, the church published its first Church Manual which described this prevailing liturgical practice.

Though Northern Blacks experienced legal freedom early in the nineteenth century, racism continued in the North. At the ordination of a Black minister, Charles Kinny, Black Adventists experienced great embarrassment when they were relegated to the back seats of the worship gathering. ${ }^{21}$ Therefore, by the 1890 s, Whites had already begun to prohibit Blacks from worshiping together, though Blacks desired to worship with Whites. At the 1891 General Conference, Kinny asserted that he and other Black folk desired to worship together, for it was a blessing. "In the first place, a separation of the colored people from the white people is a great sacrifice upon our part; we lose the blessing of learning the truth-I have reference especially to general meetings." 22 At this same General Conference, Charles Kinny ${ }^{23}$ and Ellen White, ${ }^{24}$ earnestly appealed to church leadership to begin a ministry to Blacks in the South.

The church would not cure its racism in the North, but it could share God's love in the South. In 1894, Ellen White's son, James Edson White, read a copy of his mother's appeals for the Black work in the South. He responded to the call, sailing the steamboat, The Morning Star, down the Mississippi River. In 1898, Edson White published a series of Review articles written by his mother regarding ministry to Blacks in the South, entitled, The Southern Work. The first article was Ellen White's 1891 General Conference appeal. In it, she advocated for a counter-cultural message, admonishing Black and White Adventists to worship together-even in the South-amidst racism ruling the region. ${ }^{25}$ Worshiping together was Ellen White's normative principle for churches in the North and the South. However, after 1908 , in the face of violent legalized racism in the United States, the Adventist church determined that it behooved them to gather for worship along racial lines. ${ }^{26}$ Though intended to be temporary, this division became normative. Furthermore, The Southern Work, which contextualized Ellen White's counsel on worship and race, went out of print. It was not until 1966 that the church reprinted the little volume during the Civil Rights Movement.

Despite having primarily worshiped separately during the twentieth century, Black and White Seventh-day Adventists have maintained an astounding commonality of spiritual identity. ${ }^{27}$ The central focus of Adventist spiritual identity has always been a love for Jesus Christ who is coming soon. ${ }^{28}$ Music enhanced the message: "If the pastor was going to preach about a particular part of the scripture, the music was selected to bolster that kind of mood or thinking." 29 The second coming hymnody has continued to express Adventist spirituality in the twentieth century. "Lift Up the Trumpet" was a favorite. "I "I want to see singing and music all say He's coming again, get ready, $\mathrm{He}$ is coming." 31 Wayne Hooper's hit, "We Have This Hope," has struck a chord on the heartstrings of Adventists since 1962, becoming core to Adventist spiritual identity the past fifty $_{\text {years. }}{ }^{32}$ 
Charles Bradford, the first Black President of the North American Division of Seventh-day Adventists, emphasized the shared identity of Black and White Adventists, saying, "Our worship was different from the other churches, because we are a called-out people," echoing the appeal of the angel in Revelation 18:4. ${ }^{33}$ Adventist doctrine contributed significantly to a shared spirituality, over and beyond any White supremacy. ${ }^{34}$ One Black couple, Ernest and Annelle Rogers, both of whom were about 100 years old at the time of the interview, believed the Adventist "message that we have today is a message that brings people together. With one blood, he has created all nations of the world." 35 This message is, of course, not uniquely Adventist; it is Christian. Nevertheless, Ernest's favorite hymn reflected his spirituality: “There is power, power, wonderworking power, in the blood of the Lamb." 36 Ernest, a retired New Testament professor at Oakwood University for many decades, had found a Friend in the Author of the Book he so earnestly studied.

Importantly, however, differences in worship have continued to grow and nourish Black Adventist spiritual identity. Black worship was different due to the Black experience. Services were long, lasting about two and a half hours (11:30 A.M. to 2:00 P.M.), ${ }^{37}$ allowing marginalized folk experiencing Jim Crow to cultivate community. Most Black Adventist congregations sang the Black spirituals, retelling the stories of the Black experience to each successive generation. ${ }^{38}$ "Music has been the medium through which this [Black] experience has been passed on from generation to generation." 39 In the 1930s and 1940s, Black Adventists continued to interpret the spirituals with a double entendre because the old songs spoke to the contemporary context of Jim Crow. ${ }^{40}$ Through singing the spirituals, Black Adventists embraced their common African American past, while appropriating the gospel message to their present context. For Ernest Rogers, music helped him express his experience.

\begin{abstract}
Blacks have difficulties, all types of difficulties that blacks have that whites never experienced, and when one gets to church, this is the time when they can release themselves, and express God, and thank him for his mercies. This is the thing, and black preachers know how to appeal to that emotion, and they can"Nobody knows the trouble I've seen, nobody knows but Jesus." When they can see a mother who's having difficulty with her children, when they can see a parent over here that doesn't have milk to feed and food to feed their children, you have debts and rent that you cannot pay.
\end{abstract}

[When people] come to church, they come with these burdens on their hearts, and [pastors] preach to a person uplifting sermons so as to make them feel that God is with them, and even though they are passing through trials, everything is going to be all right, and they can leave with a relief somewhat because their spirits have been satisfied. They have met God. God has spoken to their heart ... .

As I said, I came from the slums .... For others who came up in that environment, that's all they know, so to worship God means that you got to show that you love God. You got to praise him, you got to have some type of demonstrative activity to show that you really believe God, and that God is going to help you. They've gone through so many trials and temptations, and when they get to church, this is a time to release it, and they release it in praise. ${ }^{41}$

In light of White racism and its culture of shame, Black worship necessarily looked different to speak to the needs of Black Adventists, sometimes as protests, sometimes as praise. The Harlem Renaissance of the 1920s instilled in Black Adventists a desire to do the very best and most artistic music, serving as a precursor of the Civil Rights Movement, and empowering them to embrace their African roots and uplift the race in the eyes of society. Charles Bradford shared in a private interview that Black Adventists sought to make a statement to the denomination and the greater White society. "We are just as good or better musicians. We are legitimate musicians. Our worship is legitimate, and we can do the very best." ${ }^{42}$ For example, Black Adventists would protest White supremacy by performing major European works, such as Bach and Beethoven, ${ }^{43}$ Handel, Mendelssohn, ${ }^{44}$ Rossini, ${ }^{45}$ and Verdi. ${ }^{46}$ These compositions expressed and inspired "quite a lot of emotionality, but they weren't sensual." ${ }^{\prime 7}$ 
Mylas Martin (1931-) gives a rich account of Black Adventist worship music practices. He remembers the first time he entered a (Black) Seventh-day Adventist Church in Cleveland, Ohio, on January 8, 1944. For the "song of the morning," the choir sang Gioachino Rossini's Inflammatus from the Stabat Mater, "just as though it were an everyday occurrence. I was stunned."

I went back the next Sabbath and the next Sabbath to hear that choir. It was the senior choir, and they sang a great repertory of the old Advent hymns, the great Negro spirituals, the modern anthems, and the great classical master works. They sang Bach, Beethoven, Mozart ... and they sang it magnificently. It has been my privilege to travel greatly. I have been throughout Europe. I have never heard an ensemble that was more thrilling. ${ }^{48}$

Worship meets needs differently. Though a denomination may be unified in a common spiritual identity centered in its doctrine, it manifests a diversity of spiritualities based upon the human experience. All Christians seek forgiveness at the cross. However, culture impacts how they experience salvation. Whites do not experience the racism that Blacks experience in America. Regardless of economic status, White Americans come to worship from a place of power and privilege, causing them to seek God differently than Blacks. Blacks come from a place of systemic oppression, seeking freedom in Christ that is spiritual, physical, and even political. Felt needs lead Blacks to worship with joy and belonging not afforded by society.

Blacks and Whites create music differently. In the early twentieth century, Black Adventists never sang hymns like, "Immortal, Invisible, God Only Wise," and "The God of Abraham Praise." 49 These hymns were too "staid." ${ }^{0}$ Notably, Black Adventists rarely sang, "A Mighty Fortress," though it had been included in the popular songbook, Christ in Song, no. 681. The Lutheran chorales did not "lend [themselves] to the black style of singing." 51 These stately hymns were not part of the Black Adventist tradition, likely because the collective community thought these songs neither spoke to their Black experience, nor fulfilled the existential needs their own tradition had come to meet.

In the early twentieth century, Blacks and Whites worshiped similarly. By and large, they liked the same music, the same liturgy, and therefore shared very similar spiritual identities derived from their theology fostered through music.

Because Adventism also reflected the wider American society, including its racial constructs, Blacks and Whites also cultivated different spiritual identities based on their American experience.

\section{Conclusion}

Congregations can learn from this history. Musical styles do not belong to one ethnicity. Anyone can play any style of music. More important than the style of music, communities should include the cultural expressions of all the people attending that local congregation's worship. Sadly, some Christians perpetuate separation, allowing racism to continue in organizational structure, ministry, and worship praxis. This creates a culture of shame. Many Black Adventists retell their own story, or that of a loved one, in which, upon arriving at a historically White church, are told "their [Black] church" is across town.

This study ought to behoove Christians to befriend the "other," to listen to their stories, and to appreciate their worship. Preferences can change as relationships are shaped by the power of the Holy Spirit. Only by working with the Spirit, can we heal the sin of racism in America. Churches today need to be accepting so that no one is turned away from a place of worship based on race.

Unity in diversity demands that we make space for not just one common denominational identity, but a multiplicity of cultural identities within that transcultural umbrella. Our various traditions should safeguard shared beliefs, but caution is advised, lest we make particular cultural manifestations the rule for others. Our task is not a schizophrenic spirituality. It is an affirmation of our common identity as Christians, making space for the rich diversity of human expression. 


\section{Notes on Contributor}

David A. Williams is an assistant professor of worship and sacred music and co-director of the International Center for Worship \& Music at Andrews University in Michigan. His forthcoming publication is a "History of Seventh-day Adventist Worship."

\section{Notes}

1. Black and White are capitalized, as are similar ethno-socio-cultural adjectives like English, Spanish, and Jewish. It is important to note that Black and White are not monolithic. Black includes not only African American, but also Afro-Caribbean, African, and other persons of the African diaspora. African American and European American relate to ethnic heritage. In choosing the terms, Black and White, I am choosing to directly address racial categories based upon the color line. As a White American male, I recognize my own shortcomings and inherent biases in worship, music, and race. I make no claims to being an expert or knowing Black worship from the Black American experience, relying on research and the experience of interviewees to inform my investigation and conclusions.

2. Dave Unander, Shattering the Myth of Race: Genetic Realities and Biblical Truths (Valley Forge, PA: Judson Press, 2000), xvi, 8, and 100.

3. Kristen A. Renn, "Creating and Re-Creating Race: The Emergence of Racial Identity as a Critical Element in Psychological, Sociological, and Ecological Perspectives on Human Development," in New Perspectives on Racial Identity Development: Integrating Emerging Frameworks, ed. Charmaine L. Wijeyesinghe and Bailey W. Jackson III (New York: New York University Press, 2012), 11.

4. Elizabeth Higginbotham and Margaret L. Anderson, "The Social Construction of Race and Ethnicity," in Race and Ethnicity in Society: The Changing Landscape, ed. Elizabeth Higginbotham and Margaret L. Anderson (Belmont, CA: Wadsworth Cengage Learning, 2012), 3-4.

5. Dirk R. Ellis, "The Relationship Between Liturgical Practice and Spirituality in the Church of the Nazarene with Special Reference to John Wesley's Doctrine of Christian Perfection." PhD diss, Andrews University, 2012, 578.

6. Stephen A. Grunlan and Marvin K. Mayers, Cultural Anthropology: A Christian Perspective (Grand Rapids, MI: Academie Books, 1988), 225.

7. Swee Hong Lim and Lester Ruth, Lovin' on Jesus: A Concise History of Contemporary Worship (Nashville, TN: Abingdon Press, 2017), 138. Lim and Ruth speak specifically about how contemporary worship has developed a musical sacramentality in which allegiance to musical style is akin to professions of faith in baptismal liturgies.

8. Edward Yarnold, "Media of Spirituality," in The Study of Spirituality, ed. Cheslyn Jones, Geoffrey Wainwright, and Edward Yarnold (New York: Oxford University Press, 1986), 39.

9. Mary E. McGann, Exploring Music as Worship and Theology: Research in Liturgical Practice (Collegeville, MN: Liturgical Press, 2002), 9.

10. Nathan O. Hatch, The Democratization of American Christianity (New Haven, CT: Yale University Press, 1989), 145.

11. "Old Church Yard," in Joshua V. Himes, Millennial Harp. Designed for Meetings on the Second Coming of Christ, improved edition, three parts in one volume. (Boston, MA: Published at 14 Devonshire Street, 1843), 2:24.

12. James S. White, Life Incidents: In Connection with the Great Advent Movement, as Illustrated by the Three Angels of Revelation XIV.1 (Battle Creek, MI: Steam Press of the Seventh-day Adventist Publishing Association, 1868), 94.

13. Ibid., 107.

14. George R. Knight, A Search for Identity: The Development of Seventh-day Adventist Beliefs (Hagerstown, MD: Review and Herald Publishing Association, 2000), 55-58. Many scholars have written excellent work on the development of early Adventism and the establishment of its core teachings. See Rolf J. Pöhler, Continuity and Change in Adventist Teaching: A Case Study in Doctrinal Development (Frankfurt am Main, Germany: Peter Lang GmbH, 2000); Merlin D. Burt, “The Historical Background, Interconnected Development, and Integration of the Doctrines of the Sanctuary, the Sabbath, and Ellen G. White's Role in Sabbatarian Adventism from 1844 to 1849," PhD diss., Andrews University, 2002; P. Gerard Damsteegt, Foundations of the Seventh-day Adventist Message and Mission, rep. ed. (Berrien Springs, MI: Andrews University Press, 1995); Alberto R. Timm, "The Sanctuary and the Three Angels' Messages 1844-1863: Integrating Factors in the Development of Seventh-day Adventist Doctrines," PhD diss., Andrews University, 1995; Theodore N. Levterov, "The Development of the Seventh-day Adventist 
Understanding of Ellen G. White's Prophetic Gift, 1844-1889," PhD diss., Andrews University, 2011; Le Roy Froom, Movement of Destiny (Hagerstown, MD: Review and Herald Publishing Association, 1978).

15. James S. White, A Word to the "Little Flock" (Gorham, ME: n.p., 1847), 1.

16. James R. Nix, Early Advent Singing (Hagerstown, MD: Review and Herald Publishing Association), 76.

17. H.N. Stevens, "A Brief Exposition of the Angels of Revelation," Review and Herald (hereafter RH), December 23, 1851, p. 72; L. O. Stowell, “The Love of Heaven," RH, September 2, 1852, p. 72; Annie Smith, Home Here, and Home in Heaven. Part II. Home in Heaven (Rochester, NY: Advent Review Office, 1855).

18. Mr. Vincent, "The Glorious Resurrection," from The Midnight Cry, 1843, in RH, December 9, 1852, 117.4-9, https://m.egwwritings.org/en/book/1645.4216.

19. "Heaven," from Independent, in RH, October 13, 1859, p. 167.

20. Benjamin J. Baker, "I Do not Mean to Live a Coward or Die a Coward': An Examination of Ellen G. White's Lifelong Relationship to Black People,” PhD diss., Howard University, 2011, pp. 34-56.

21. Delbert W. Baker, "Events Leading to the Establishment of Regional Conferences," in Telling the Story: An Anthology of the Development of the Black SDA Work, ed. Delbert W. Baker (Nashville, TN: Black Caucus of SDA Administrators, 1996), 7.

22. “C.M. Kinney's Statement on the Concept of Regional Conferences," October 2, 1889, in Baker, Telling the Story, 2:8 (see n. 21).

23. Charles M. Kinny, the first Black ordained minister, has been called the "Father of Black Adventism." Ronald D. Graybill, "Charles M. Kinny: Founder of Black Adventism," RH, January 13, 1977, pp. 6-8.

24. Delbert W. Baker, "In Search of Roots: Adventist African-Americans Part 1, Exploring the History," $R H$, February 4, 1993, p. 14. Ellen G. White was one of the founding leaders of the Seventh-day Adventist Church, along with front-runner, James S. White, and their elder minister, Joseph Bates. For more on Ellen White, see Denis Fortin, ed., The Ellen G. White Encyclopedia (Hagerstown, MD: Review and Herald Publishing Association, 2013).

25. Ellen G. White, "Our Duty to the Colored People," in The Southern Work, ed. James Edson White, rep. ed. (Hagerstown, MD: Review and Herald Publishing Association, 1966), 15 and 20.

26. Ellen G. White, Testimonies for the Church (Mountain View, CA: Pacific Press Publishing Association, 1948), 9:206-207; R. Clifford Jones, James K. Humphrey and the Sabbath-Day Adventists (Jackson, MS: University Press of Mississippi, 2006), 100.

27. For this research I conducted oral histories with twenty-nine Black and White Adventists with memories of Adventist worship between 1920-1950. Retelling their memories in the 2010s gave insights into a spiritual identity that has continued even to the present time.

28. Beverly and Ralph Benedict, oral history by David Williams, Battle Creek, MI, March 14, 2017, 24.25-28, and 30-31. This oral history, and all subsequent histories may be found at the Center for Adventist Research in the James White Library of Andrews University, Berrien Springs, Michigan. All subsequent designations for oral histories refer to transcriptions from audio recordings. Citations refer to the page and line number of the documents.

29. Elihu McMahon, oral history by David Williams, Harlem, NY, October 5, 2014, 17.6-7

30. Benedict, oral history, 23.31-33 and 24.2 (see n. 28); James North Jr., oral history by David Williams, Andrews University, Berrien Springs, MI, September 29, 2014, 28.14; Annelle and Ernest Rogers, oral history by David Williams, Huntsville, AL, September 25, 2014, 22.16; Claude and Jocelyn Thomas, oral history by David Williams, Huntsville, AL, September 25, 2014, 11.10.

31. Claude and Jocelyn Thomas, oral history by David Williams, Huntsville, AL, September 25, 2014, 17.22-23. What Jocelyn Thomas says about the content of the songs indicates that Adventists today do not reflect the second coming often in their congregational song.

32. Bette Anderson, oral history by David Williams, Battle Creek, MI, March 22, 2017, 8.22, 31 and 12.32-33; Benedict, oral history, 23.21-22 (see n. 28).

33. Charles Bradford, unrecorded oral history interview by David Williams, Huntsville, AL, October 2013.

34. Charles and Ethel Bradford, oral history by David Williams, Huntsville, AL, September 26, 2014, 4.23-25 and 29-30.

35. Rogers, oral history, 19.38, 20.4-5 (see n. 30).

36. Ibid., 22.5-11.

37. North, oral history, 3.1-7 (see n. 30).

38. "[Singing the spirituals] kept before us our fore-parents, forefathers. My grandmother was a slave. My great grandmother was a slave." Lovey Verdun, oral history by David Williams, Huntsville, AL, September 25, 2014, 14.24-25.

39. Lucile C. Lacy and Eurydice V. Osterman, "Music at Oakwood," Adventist Heritage: Special Oakwood Edition, no. 17.1 (March 1996): 38. 
40. Interview Notes \#EPH10614, by David Williams, Harlem, NY, October 6, 2014, 1.11-18. Because the research subject requested anonymity, no audio or interview transcript is available. This reference, however, is to the interview notes which are available.

41. Rogers, oral history, 14.20-36 (see n. 30).

42. McMahon, oral history, 14.33-37 (see n. 29).

43. Ibid., 13.37 .

44. Thomas, oral history, 5.27-33 (see n. 31).

45. McMahon, oral history, 8.5-8 (see n. 29).

46. Ibid., 15.2.

47. Thomas, oral history, 6.12-13 (see n. 31).

48. Mylas Martin, oral history with Merlin Burt, James White Library, Andrews University, Berrien Springs, MI, April 23, 1997, 20.

49. North, oral history, 28.7-8 (see n. 30).

50. Bradford, oral history, 10.30-31 (see n. 34).

51. North, oral history, 28.32-36 (see n. 30). 